Article

\title{
Education in the Times of Demographic Change and Globalization. Case Study on the Example of the Silesian Voivodeship
}

\author{
Ryszard Marszowski *, Leszek Drobek, Piotr Hetmańczyk@ and Małgorzata Markowska \\ Central Mining Institute, Gwarków 1, 40-166 Katowice, Poland; ldrobek@gig.eu (L.D.); \\ phetmanczyk@gig.eu (P.H.); mmarkowska@gig.eu (M.M.) \\ * Correspondence: rmarszowski@gig.eu; Tel.: +48-32-25-92-183
}

Received: 3 May 2020; Accepted: 9 July 2020; Published: 15 July 2020

check for updates

\begin{abstract}
In light of the content contained in this article, in the context of demographic change and globalization, there can be no doubt that education responding to contemporary challenges is a guarantee of promoting knowledge and profiling mobile and adaptive qualified staff characterized by having a specific level of knowledge, unique skills and highly developed qualifications. It is widely recognized that knowledge is the decisive factor in competitive advantage. The dynamics of changes taking place are conditioned by the resource and innovation of people's knowledge, quality of work, education and training, the ability to think quickly and be innovative and implement new solutions in the process of production, distribution and services. The authors of the article justify why education should be seen as a value in all social and individual interactions, especially in a situation of economic change, globalization and demographic transition. It should refer to the inspiration of change, but also to the stabilization of people's situations. Learning and education is therefore a modern value. Hence, it is important to perceive the strength and value of education in every social situation.
\end{abstract}

Keywords: education; second demographic transition; globalization

\section{Introduction}

The article combines both the research and analytical area, as well as he practical application of the accumulated knowledge. Research in the area of relations between education and demographic change and globalization is the key topic of the first (education in the perspective of the demographic change) and the second part (education in the perspective of globalization) of the article, respectively. Due to the cognitive areas undertaken in the article, their scale and their quality, the authors referred, in key parts of the article, to the extensive-current and international-literature and interdisciplinary research. Both the literature and research findings confirm the need to recognize that education should be seen as a value in all social and individual declarations. It should refer to the inspiration of change, but also to the stabilization of man. Thus, learning is an asset of modern times.

Therefore, the authors in the article undertake analyses and justifications of the thesis that education and the quality of human capital are one of the most important development factors of modern societies, in the perspective of demographic changes and globalization.

In light of the above objectives and trends and regularities, it is worth noting that, according to demographic forecasts, by 2030, the number of people of working age in the European Union will drop by almost 21 million and the population of young Europeans will decrease by $20 \%$ over the next twenty years. This change is one of the key challenges facing modern Europe in the field of education. This is very clearly noted by the European Expert Network on Economics of Education (EENEE), 
which in report "The Future of European Education and Training Systems: Key Challenges and Their Implication", places demographic change first of the four key challenges for education and training systems [1]. In this light, the results of studies by Schlotter and others which emphasized that $60 \%$ of new types of work performed in the 21st century will require skills that are currently only held by $20 \%$ of potential employees, are of particular importance. Therefore, the challenge is to promote modern attitudes and make people aware that a departure from the dominant way of thinking in the industrial age is necessary and inevitable, because only turning to the future-through care of one's own development-can be a guarantee of success [2] (pp. 241-242).

This thesis develops a description of the function of contemporary education by Rostańska, which states that education is perceived as a value in all social and individual declarations and its importance cannot be overstated. It refers to the inspiration of changes and stimulation of development, but also to human stability. She also perceives education as the perpetrator of activity and as an object of human activity. Hence, there is an undeniable role of the strength and value of education in every social situation [3] (p. 12). The extremely important functions and megatrends in thinking about the future of (vocational) education cannot be omitted. An attempt to develop and anticipate them is made in the text below, which focuses on education perceived through the second phase of demographic transition and globalization - in the formula of conditions and forecasts for the area of the Silesian voivodeship.

\section{Materials and Methods}

In accordance with the main objective of the article, which is the analysis of the importance of education in phase of demographic change and globalization-and the assumptions, theses and megatrends adopted in the introduction to the article-a variety of research methods was used in the research, including: analysis and criticism of literature (desk research), dogmatic legal, statistical and descriptive and scenario forecasts. The indicated research methods focus mainly on cognitive areas, which are: globalization, demographic change and the socio-demographic and economic development conditions of the Silesian Voivodeship, in the context of education corresponding to contemporary challenges.

The analysis and criticism of literature covered numerous pieces of complementary work and focused mainly on the processes and megatrends determined by globalization and demographic, technological and macroeconomic changes, shaping the state and development perspectives of education responding to contemporary challenges. The main purpose of the method was to refer to the available public, scientific and professional literature, thanks to which the analyzed problem area was examined. The conclusions and recommendations resulting from them are intended to strengthen the utilitarian part of the analyses carried out. The analysis and criticism covered both theoretical publications and publications discussing research results and forecasts in numerous cognitive cross-sections.

The analysis also made use of other studies devoted to the development perspectives in light of strategic documents regarding future. Included in these documents were the multi-annual development strategies for Europe, the country (Poland) and the voivodship (Silesia), in various quality sections. In addition to formal and legal issues related to the development perspectives of the studied areas, this included, among others in applicable law, the studies referred to in the European and national documents in which medium and long-term goals and tasks in the field of economic and social policies were outlined, especially in the context of the above-mentioned ongoing and forecasted demographic processes.

In turn, the key purpose of using descriptive statistics was to determine the regularities taking place in the Silesian Voivodeship and to reflect their diversity occurring in phenomena determining its development perspectives-in particular at the demographic change stage.

Scenario forecasts, from the perspective of demographic change and globalization, focus on predicting both future internal and external development conditions, in order to achieve the desired target state, i.e. the justified need and vision of education in response to contemporary challenges. When 
presenting forecasts, it is assumed ex ante that the specificity of the area under study sets preferences outlining organizational and systemic solutions directly related to the future education model. It is also assumed that the current strategic and planning documents at the European, national and provincial levels have numerous indications, recommendations and supporting premises enabling them to infer the target education model. It is also assumed that the current state of the coronavirus epidemic in the territory of the Republic of Poland will accelerate the implementation-as an unfavorable circumstance - of numerous elements of the anticipated forecasts.

\section{Discussion}

\subsection{Education in the Perspective of the Demographic Change}

Demographic and social transformations result from the overlapping of four basic interactions, i.e., business cycles, globalization, second demographic transition and suburbanization [4] (p. 229-244). The creator of the second demographic transition (SDT) theory, Dirk J. Van de Kaa, draws attention to the need to describe and anticipate, first and foremost, the stages of demographic development of humanity and on this plane, as well as his theory of attempting to formulate demographic forecasts and their impact on numerous spheres of social and economic life, with particular emphasis on education. As Sztanderska notes, significant changes in the number of children and young people are the reason for the need for significant changes in education. Demographic changes are not one-way, so adjustments cannot be one-sided [5]. It is worth noting here that the French demographer Adolphe Landry (1909), who at the beginning of the 20th century developed a theoretical concept explaining the demographic development of the world. Over time, his concept took several characteristic names, such as demographic transformation, phase development or cyclical demographic transition. This was the result of its development and numerous further researchers [6]. Despite these works, the basic assumptions shaping Landry's ideas did not change. According to this approach, population development for each large social groups follows several successive time phases, differentiated due to the characteristic development of the natural movement of the population determined by the number of births and deaths. This process throughout history—from a society living in primitive conditions to a society operating in a globalized world and rich knowledge-based economies-has been universal. Demographers, attempting to explain the sources and implications associated with changes in the quantitative and qualitative structure of the natural movement of the population, distinguish five key stages of its development:

Phase I means a small demographic increase. This is characteristic of people living at a low level of economic development. It is characterized by a very high birth rate associated with an equally high level of mortality. This condition can lead to very low rate of natural increase, which in socially and economically critical situations (widespread hunger, armed conflicts or mass epidemics) then takes the form of a large natural loss. In this phase, the average life expectancy is very low and does not exceed thirty years, while the percentage of children in the total population is very high.

Phase II is determined by an intensive demographic increase with a simultaneous-yet still high-percentage of births which is, however, characterized by a noticeable, though small, decrease. However, as a result of the development of medicine, hygiene and improving living conditions, the death rate is clearly falling. As a result, the birth rate is very high. The period in which these processes occur is called demographic explosion or abrupt population growth in demography.

Phase III is a time of moderate demographic growth. This is the period in which the traditional multigenerational family model is slowly disappearing. The number of births is systematically falling, and the mortality rate is also falling. Natural increase is decreasing but remains at a level that secures the replacement of generations. The average life expectancy increases with the appearance of the symptoms associated with an aging population. The percentage of people of a young age is still high in this phase. 
Phase IV is characterized by demographic stagnation. In this phase, the process of a further decline in the number of births and the number of deaths remains at a constant level can be observed. As a result of the changes taking place, natural increase gradually approaches zero. Aging is increasingly evident, with the average life expectancy increasing significantly to eighty years.

Phase $\mathrm{V}$ is a time of demographic decline. In this last phase of demographic change, the number of births is clearly lower than deaths. Natural depletion complements the influx of migrants, which lead to some serious phenomena and political and social problems. Population aging is a dynamic phenomenon associated with the reversal of the age pyramid. The working age population is clearly decreasing with a dynamic growth of the post-working age population and the population of people over 75 years old.

The phenomena associated with the fourth and fifth phases of demographic development are currently permanently shaping social relations in economically developed countries. This fact and the consequences resulting from it determine the emergence in demography of new theoretical hypotheses and research questions directly related to the relationships between the size of births and deaths. On the basis of these relationships, a new approach was created in describing demographic phenomena, referred to as the "second demographic transition theory", as previously mentioned. This approach distinguishes four characteristic determinants, which-according to the creator of this theory, D. Van de Kaa-are:

- decreasing the importance of marriage as a form of human co-habitation for cohabitation;

- transition from family model "the king-child with parents" focused on a child(ren) to the model called "the king-pair with a child" putting emphasis on a relationship of the couple;

- the transition from preventive contraception to conscious procreation;

- transition from homogeneous types of families and households to various forms [4] (p. 11).

In light of Van de Kaa's theory, the development of the demographic structure of the population in the second demographic transition mostly determines the decrease in fertility, as a result of which the level of natural increase becomes negative values [4] (p. 11).

More specifically, sources of fertility decline should be highlighted by the following factors:

- $\quad$ promoting pre-marital sex;

- delay in getting married;

- diversification and dissemination of alternative forms of partnerships;

- increasing the phenomenon of permanent celibacy (remaining outside partnerships);

- increase in divorce severity;

- universality of single-parent families;

- the multitude and diversity of partnerships throughout the life of the individual;

- reducing the proportion of people in formal marriages;

- reducing the average number of children in the family;

- disappearance of many children;

- increase in voluntary childlessness;

- popularizing contraceptives;

- delaying the age of procreation.

According to D. Van de Kaa, in the mid-1960s, a qualitatively new phenomenon occurred, i.e., there was a discontinuity in the reproduction of the population. This was due to, in Western Europe, there being a radical reevaluation of the family. Instead of investing in the future of their children, parents focused on self-realization. This resulted in the transformation of the family model from "bourgeois" to "individualized".

As a result of changes and long-term forecasts, according to expert assessment, demographic changes will have a significant impact on the future shape of education and school systems [7]. 
The most serious challenge is the need to adjust all levels of education to the change in the age structure of the population due to demographic depression. Furthermore, the need to improve people's competences by promoting the idea of lifelong learning is also a significant challenge. As a result of the aforementioned aging of the population, it should be noted that future European labor resources will come from significantly older members of the population than they do currently. This is connected with another challenge, which is the need to update current training systems in order to adapt them to the needs of aging societies, from which the dominant percentage of employees will come and the quality of their employment and efficiency of work will depend on Europe's development and competitiveness. An equally serious challenge is the aging of the teacher population. This process determines the need for providing high-quality qualified staff in the education system for the education and training system, together with the need to recruit new and talented employees in the face of market competition [8] (pp. 127-142).

It is widely recognized that demographic change in metropolitan areas in Europe is linked to falling birth rates and migration. Migration is increasingly intense and is becoming the dominant factor in population growth. These processes are particularly determining changes in population development in western and central-eastern Europe. They are-as has already been noted-related to the decline in natural growth occurring since the 1960s and the increase in urban-rural housing migration. On the other hand, in Eastern Europe there is a reverse process, related to the rural-urban migration directed to the city core, accompanied by a relatively high natural growth [9]. After 1989, urban areas were the first to be affected by a decrease in population resulting from a dramatic drop in the natural growth, as well as a drop in migration. Currently, there are many cities characterized by a negative change in population accompanied by a negative net migration (outflows to suburban areas) and a negative natural growth. All these changes are related to the already mentioned second demographic transition [10]. The main features of this change are a decrease in fertility below replacement levels, an increase in the average age of mothers in the period of highest fertility, a decrease in the number of marriages and an increase in the number of divorces. It is worth emphasizing that the decline in fertility results from changes in attitudes towards having children and, more generally, towards the family, related to the destabilization of traditional family structures, including postponement of procreation decisions and increased diversification of household status (e.g. increase in the number of childless couples).

In view of the processes, phenomena and megatrends outlined above, the Silesian Voivodeship is an example, in the area of Poland undergoing intensive and systematic social and economic transformations. At the same time, it is an area which influences the processes taking place in the dimension of the whole country, determining their scale and dynamics.

In terms of economy, the Silesian Voivodeship is one of the strongest in Poland. A total of $13.1 \%$ of Poland's gross domestic product (GDP) is generated here, giving the Voivodeship the second highest rank in Poland. The economic transformations going on in the region have resulted in a significant change in the structure of the gross added value (the newly produced value) generated in the region. The share of market and non-market services accounts for nearly $60 \%$ and industry $33 \%$, ranking the Silesian Voivodeship first in Poland. The Silesian Voivodeship is rich in natural resources, such as hard coal, deposits of zinc, lead, methane, natural gas, marlstone, chalkstone and natural break-stone, as well as medicinal, thermal and mineral waters. The existing raw material base led to the creation of Poland's largest industrial region. Now, in the process of restructuring, traditional Silesian industries have become the basis for the development of industries related to their functioning, that is, first of all, the machine industry, equipped with appropriate machines and experienced staff. After the difficult transformations introduced in the first years of the 1990s, the industry entered numerous foreign markets and is now a crucial element of the industrial landscape of the Voivodeship. Restructuring in recent years has caused systematic changes in the economic structure of the Voivodeship. The whole industry reports a decreased share of mining and metallurgy, which until recently were predominant in the economy of the Voivodeship, and an increased share of 
the electro-engineering industry, the information technology industry, power industry and, reporting the most rapid growth, the automotive industry (the region is Poland's largest car producer) and food industry. Over 451,000 national economy entities are registered in the Silesian Voivodeship. The largest part is comprised of natural persons running a business activity and companies and commercial law partnerships. The least numerous is the group of state-owned enterprises [11].

In this context, it is worth noting that, against the background of the qualitative processes described above, as described in the Van de Kaa theory, at the end of the 20th and the beginning of the 21st century, there were numerous changes in the structure of the population of the Silesian Voivodeship characterized, with the following unique:

- it is the most urbanized region of Poland. The density of the urban network, which is expressed by the square $\mathrm{km}$ territory per 1 city, is also the highest in Poland;

- the number of cities, amounting to 71, is inferior to the Wielkopolskie Voivodeship, which has three times the area;

- there are complex agglomerated systems in the form of conurbations (Katowice conurbation), polycentric agglomerations (e.g., Rybnik agglomeration), microconurbations (Radlin-PszówRydułtowy) and urban complexes (Zawiercie-Myszkowski). In addition, there are two large monocentric agglomerations-Bielsko-Biała and Czestochowa,

- there were a significant number of cities that arose as a result of 19th and 20th century industrialization;

- the average administrative area of the city is clearly above the national average;

- there is a large group of highly specialized industrial cities;

- there is a specific category of rural and urban communes that were established in the 1990s as a result of the breakup of large cities [12] (pp. 16-21).

In the space created, the key trends regarding the structure of the voivodship's population in the 1990s and from 2004 to 2017 were as follows. Until 1988, the population growth process continued in the Silesian Voivodeship. During the period of political and economic transformation, population stagnation occurred, as a result of which deepening demographic regression begins. These changes were accompanied by a strong increase in the share of people aged over 60 . As a result, demographic depression occurred in the 1990s. In quantitative terms, Table 1 illustrates these changes.

Table 1. Population of the Silesian Voivodeship. Changes in 1978-2017*.

\begin{tabular}{ccc}
\hline Specification & Year & Voivodeship (Thousand) \\
\hline Population & 1978 & 4535.5 \\
Natural balance & $1979-1988$ & 3387 \\
Balance of migration & 1988 & 1365 \\
Population & $1989-1998$ & 4900.1 \\
Natural balance & 1998 & 46.5 \\
Balance of migration & $1999-2008$ & 12.3 \\
Population & first half of the year & 4797.7 \\
Natural balance & & -46.6 \\
Balance of migration & $2008-2018$ & -96.3 \\
Population & & 4533.5 \\
Natural balance & & -8.5 \\
Balance of migration & & -4.8 \\
\hline
\end{tabular}

Source: own calculations based on the Statistics Poland Local Data Bank. 1978-2018.

In this context, as noted by J. Runge in 1991, the Silesian Voivodeship achieved the maximum of its post-war population significance. Since 1993, cities have been permanently negative in the migration balance, and rural areas positive. The centuries-old-reaching the second half of the 18th century-period of significant importance of the migration influx in creating the labor market of the Silesian Voivodeship, and also the population of cities [13] (p. 279). In the Silesian Voivodeship, 
there were characteristic changes for the fourth phase of demographic transition (demographic stagnation) [14] (p. 136): the number of births is decreasing and the number of deaths remains at the same level, which leads to the deterioration of the natural balance, which remains negative.

The aging process of the population becomes more and more visible, and the average life expectancy is increasing, reaching 80 years.

The indicated changes confirm the figures. In the years 2004-2018, the downward trend in the number of people living in the Silesian Voivodeship deepened. During this period, the total population decreased by 167,271 people. Compared to 2004 , this was a $3.6 \%$ drop in the total population of the Silesian Voivodeship. However, compared to the end of the $1980 \mathrm{~s}$, the decrease was $7.5 \%$, i.e., nearly 366,000 . people. In cities, the trend of a further decline in population is also visible. Rural areas in the period under assessment remained the model of previous years under the influence of population growth. The population density in the Silesian Voivodeship decreased from 399 people per $\mathrm{km}^{2}$ in 1988 to 368 people per $\mathrm{km}^{2}$ in 2018. This is a decrease of $7.8 \%$. The voivodship's share in the population of the country also decreased, from $12.9 \%$ in 1988 to $11.8 \%$ in 2018 . This indicates the severity of unfavorable demographic trends in the Silesian Voivodeship, compared to other areas of the country. As noted earlier, until 1988 the population increased and then, in the period of political and economic transformation, the processes of population stagnation and soon the deepening demographic regression began.

The reasons for such a strong decline in the number of people in younger generations include [15]:

- the demographics of the 1990s (entering the reproductive age of the generation of the 1960s);

- intensification of moral changes (e.g., consumer lifestyle and secularization) and changes related to economic transformation (e.g., availability of employers and fear of losing a job);

- $\quad$ rising living costs in conditions of economic hardship and rising unemployment.

The intensification of demographic aging processes results from the impact of several further factors, which are [16]:

- intensification of social changes affecting the reproduction pattern not ensuring the biological sustainability of generations, which reduces the number of people in younger generations. The following changes occurred most strongly in cities;

- effects of the demographic decline;

- the previous demographic low generation entering the reproductive age in the 1990s, which affected the small number of younger generations;

- stopping of the migration of young people, or even the migration outflow of young people outside the region (mainly abroad), who due to the lack of attractive work in their place of residence choose temporary migration, which delays the age of marriage and giving birth to the first child;

- improved living conditions, which extends the average life expectancy.

As a result of the described tendencies, one of the key components of demographic processes, which is population growth, with the passage of years in the Silesian Voivodeship, assumed the abovementioned negative values. In the years 1979-1988, the population growth in the Silesian Voivodeship was positive and amounted to 338,700 thousand people in total. The years 1989-1998 brought a crisis in natural growth, which amounted to only 66,500 people, i.e. it accounted for only $19.6 \%$ of the birth rate from previous years. In the years 1999-2008, a natural increase became more significant during the crisis. During this period, the natural loss reached the level of $-46,700$ people. The trend of permanent natural defect was consolidated in the following years, i.e., 2009-2018, which amounted to -5500 people. It is worth noting that the first negative natural defect in the Silesian Voivodeship was observed in 1996. From 1998 to 2017, this loss amounted to 52,100 people [17].

The described conditions determined the development of subsequent demographic coefficients, including the fertility rate and the gross reproduction rate. In 2003, the fertility rate was only 1100 children, and although an increase to 1424 in 2017 can be observed, it still does not ensure the 
sustainability of the generations. In this context, it is worth noting that narrow reproduction, i.e., lack of generational substitution, is manifested in the fact that there are less members in children's generations than the generations of their parents. This situation causes the society to die out. In turn, gross reproduction rates of 0.704 in 2003 and 0.693 in 2017 do not guarantee biological reproduction of the population in the Silesian Voivodeship This only provides a factor of 1.0. To obtain it, the fertility rate should be maintained at the level of 2.14 [18].

Along with these unfavorable regularities in the Silesian Voivodeship, a clearly disturbed feminization ratio can be observed, which is another regularity that greatly affects the future demographic situation of the voivodship [19]. It is worth recalling that in the age group characterized by the highest fertility rates, i.e., 25-29, the feminization rate shows a serious shortage of women, at 96 women per 100 men, which is the same in the 20-24 age group; however, this number increases to 98 women per 100 men in the 30-34 age group. There was also dynamic population reduction in the youngest years; a decrease in the number of children and adolescents in each analyzed age group is forecasted, and in all age groups of children and adolescents it will be greater than on a national scale. In the age group $0-2$ years, the percentage will fall from $2.9 \%$ to $2.3 \%, 3-6$ years from $4.1 \%$ to $3.2 \%, 7-12$ years from $5.2 \%$ to $4.8 \%, 13-15$ years from $2.7 \%$ to $2.4 \%, 16-18$ years from $3.0 \%$ to $2.4 \%$ and 19-24 years from $7.5 \%$ to $5.1 \%$ [20]. This change will be accompanied by the aforementioned serious decline in the number of the youngest members of the population, the children and youth. According to forecasts, by 2035 in Poland, the population of children aged 0-2 years will decrease by over 30\%, $3-5$ years by $25 \%$ and in the population of $6-14$ years by about $16 \%$.

This is one effect of the demographic depression's numerous development problems regarding the population structure of the Silesian Voivodeship. Among them the most serious issues include:

- $\quad$ post-war baby boomers entering retirement age;

- further deformation of the gender structure, increase of feminization, especially in older age groups;

- limiting the replacement of generations in the regional labor market;

- $\quad$ persistence of adverse changes in the structure of the unemployed (university graduates) [21] (pp. 286-287).

More specifically, the dynamic aging process of the voivodeship's inhabitants will become a permanent phenomenon in the next few decades. According to the Statistics Poland's forecast [22], in 2050 the population of the Voivodeship aged 65 and over may increase by $20 \%$, representing over $34 \%$ of the total population of the voivodeship. This state will in the next decade lead to a clear decline in labor supply and a dynamic increase in the demographic load indicator, which will directly increase pressure on satisfying social security benefits and will significantly affect the reorientation of the education system, requiring its adaptation to the needs of the elderly. As a result of shifting individual cohorts in the demographic structure of the voivodship's population, the population of the youngest ages will clearly decrease and the population those in their senior years will increase. If the forecasts set out above are fulfilled, the largest decreases will occur in the number of people aged 30-34 falling by $55.6 \%$, in cities the number of people aged $25-29$ will fall by $55.1 \%$, whereas in the countryside the number of people aged $25-29$ years will fall by $39.8 \%$ and aged $22-24$ by $37.3 \%$. Population growth, both in cities and in the countryside, will occur among people aged 85 and over, by almost $273 \%$ and over $280 \%$ respectively.

With regards to working age population decline, in the Silesian Voivodship in 2050, compared to 2013, it is one of the largest in the country (after the Opolskie and Świettokrzyskie Voivodships) and is forecasted to decrease the number of people of pre-working age from $16.9 \%$ to $14.3 \%$, productive age from $64,1 \%$ to $55.2 \%$ and post-production age from $19 \%$ to $35 \%$. In the Silesian Voivodship, the negative natural increase, to the end of the forecast horizon, will be the lowest in the country (a decrease from -6300 to $-23,400$ in 2050) and the decrease in the demographic dynamics ratio will be from 0.9 to 0.5 .

If the indicated changes follow the Statistics Poland's forecast, Silesia will be an example of a dramatic demographic situation with weakening human and social capital which will have significant 
social effects by 2050. This will be caused by the depopulation of numerous cities and, mass foreign emigration, natural disruption, lack of substitution generations and the aging of the population.

It is also worth noting that demographic changes in Silesia are a reflection of economic conditions. They run with different dynamics in spatial systems [23] (pp. 21-33). As European experience shows, the approach to this issue cannot be fragmentary, but must be holistic and in line with the concept of the life cycle. In a broader context, the data indicated above implies the need to pay attention to the relationship between the situation of young people on the labor market and the forms of their support for a smooth transition from education to employment. In this area, it is important to clearly emphasize the importance of programs and activities in which young people are trained to become a population of creative, mobile people who, despite the difficulties they encounter, become successful. This is essential as there are one hundred million young people living in the European Union upon whom the success of the current Europe 2020 strategy depends. In this context, it seems that the priority in the process of the preparation and implementation of activities aimed at strengthening the chances of young people on the labor market after completing education; there is a new look at the professional orientation of this social group, through such processes as:

- economic shocks;

- demographic change;

- social exclusion;

- attitudes contesting legal order and social order.

In this context-from the point of view of investing in the development of human resources-it should be noted that the globalization process, internationalization and knowledge-based economy are fully correlated with the level of human knowledge, and to a lesser extent, with material, natural resources and workforce. The domination of human capital results in its influence on shaping all other factors and its recognition as a key factor in global development. Numerous literature sources emphasize that without the participation of investments in human capital, economic development is impossible to achieve [24] (pp. 91-104). It is this capital that will determine the condition of the national economies of the European Union and the distance in their development. Therefore, it is assumed that the necessary and indispensable condition for the development of economies is the sustainable development and strengthening of human capital, along with the recognition of this action as an imperative of modernity [25] (pp. 16-28). Along with the indicated economic benefits resulting from investing in the development of human capital, the quality of life-its level and numerous social benefits-also develop, such as a decrease in crime, strengthening social ties, increase intolerance behaviors, environmental awareness and actions for the protection of the natural environment also develop. A very positive role in these areas is played by the education system, thanks to which the development of human capital influences the formation of social rules and standards and determines social cohesion. As a result, actions taken in the economic sphere create a benefit for the whole society and enable a fair distribution. These are activities that create favorable conditions for increasing the possibilities of using and creating resources and increasing the already mentioned investments in human capital.

In this light, education not only focuses on transferring knowledge and shaping skills, but also creates immeasurably valuable social capital for the knowledge economy. As indicated by numerous sources, as a result of the disappearance of social capital, the society is threatened with disintegration, which can be observed nowadays using the example of many countries. Secondly, it is recognized that social capital is a very important factor, which is the achievement of social and economic goals. This regularity can be expressed in the following relationship: the more developed social capital, the greater the chance of success in the activities undertaken. As Fukuyama observes, the pro-developmental impact of social capital occurs in the conditions of relationships shaped on the basis of the principle of respect for good common norms and values resulting from the culture of a given society, such as loyalty, honesty and integrity [26], (p. 46). Education plays an extremely important role 
in this area, teaching ethical valuation and shaping the use of universal cultural norms, significantly reducing the costs of activities in the area of economy (e.g., shaping attitudes of opposition to destroying available resources or increasing responsive responsibility for the work performed). At the same time, it affects the reduction of tensions in multicultural communities. As a result, it determines more dynamic and stable progress in the economic development of the country or region [27] (pp. 15-16).

\subsection{Education in the Perspective of Globalization}

The term "globalization" was first used in the mid-1980s [28] and during this period, Dicken referred to significant changes that took place in the global economy and were determined by the increased freedom of economic relations, the withdrawal of the state from an active role in the economy, the internationalization of capital, the third industrial (scientific and technical) revolution and the growing importance of global corporations. Among the many definitions of the term globalization in literature, the following approaches can be found: According to Liberska, globalization means a progressive process of the integration of national and regional markets into one global market for goods, services and capital [29] (Liberska 2002). Zaorska defines this term differently, stating that globalization is a long-term process of integrating national economies, sectors, markets and enterprises by expanding and intensifying cross-border trade, and institutional, cooperative and information links, which lead to the creation of increasingly stronger interdependencies in the global economy [30]. According to the Dictionary of Management and Finance, the term globalization means the process of converging tastes and product offerings around the world, as a result of which demand is satisfied with a global rather than a local product [31] (p. 76). On the other hand, according to Levy, globalization refers to the growing integration of national economies through international trade and foreign direct investment, as capital becomes more and more mobile and technologies facilitate communication, borders of individual countries become increasingly permeable to international business [32] (pp. 343-360). Levy presents a definition similar to that of Stiglitz, claiming that globalization is a closer integration of countries and people in the world, caused by a huge reduction in the costs of transport and telecommunications and the abolition of artificial barriers in the flow of goods, services, capital, knowledge and people from country to country [33]. The British economic journalist Martin Wolf describes globalization in an extremely colorful manner, writing about globalization as a journey. He states that it is a journey to an unreachable destination: a globalized world. A globalized economy can be defined as one in which neither distance nor national borders restrict economic transactions. It would be a world in which transport costs would be zero and barriers created by different jurisdictions would disappear [34] (p. 178).

In the global economy, it is now assumed that knowledge is the determining factor for competitive advantages. The dynamics of changes taking place in globalized economies are conditioned by the resource and modernity of people's knowledge, quality of work, education and training, ability to think quickly and innovate and implement new solutions in the processes of production, distribution and services [35] (pp. 77-83). In this light, as indicated by numerous studies and strategic documents, for the development of national, regional and global economies, investments in science and education are of particular importance [36] (pp. 307-318).

As globalization processes carry many risks [37], therefore, the opportunities and threats associated with globalization processes should be considered in different areas of life, such as politics, economy, society, human relations, culture and demography, etc. The opportunities and threats resulting from the processes of globalization and integration should also be reflected in curricula and educational processes at all levels of education.

At the same time, a much more serious challenge is the need to adjust all levels of education to the changes in the population age structure resulting from demographic depression [38]. Furthermore, there is a need to improve people's competences by promoting the idea of lifelong learning. As a result of the aging of the population, it should be noted that future European labor resources will come from significantly older members of the population than currently. This is connected with 
another challenge, which is the need to update current training systems in order to adapt them to the needs of aging societies, from which the dominant percentage of employees will come, as the development and competitiveness of Europe will depend on the quality of their employment and efficiency. An equally serious challenge is the aging of the teacher population. This indicates a need for providing high-quality qualified staff in the education system for the education and training system, together with the need to recruit new and talented employees in the face of market competition [39].

There is a need for the skillful forecasting of the future reality and permanent adaptation to changes taking place in the education system and in enterprises that intend to survive and develop, through proper strategies and the permanent shaping of processes occurring inside them [40] (pp. 15-23). In light of these conditions, building a suitable qualitative and quantitative education system which responds to contemporary challenges is a major challenge. In this area, the shortage of skills and qualifications necessary to create and implement innovative solutions is significant. A serious barrier is the lack of qualified staff who are prepared, in terms of the competences needed in industry 4.0 [41] (pp. 296-307). Other issues which are connected to this challenge are: the low level of digital skills and the need to retrain employees, adapt new work and organization models, as well as the need for strategic planning in the area of the education system, including in particular professional development [42]. At the same time, competences related to the concept of the so-called silver economy, understood as a socio-economic system that on the one hand is focused on using the potential of older people on the labor market, and on the other hand takes into account their needs as consumers [43].

Against this background, both the quantitative and qualitative change process regarding staffing needs is shaped. Unfavorable demographic changes and the related aging of the population, as well as increased migration away from Poland, further weaken the perspective of providing the national economy with adequate, well-qualified and creative staff. When considering, for example, the time needed to complete university or high school, starting from the moment of making a decision about education in a chosen specialization, it seems that interdisciplinary recognition of staffing needs significantly supports the accuracy of educational decisions [44]. In this context, when analyzing the chances of finding employment, it is worth noting that less than half of young entrepreneurs perform activities in line with their education, yet it is important to recognize that the knowledge and skills obtained at school and university are satisfactorily useful. In the area of creativity related to young people setting up their own businesses, there is stagnation and, in many cases, ambivalent attitudes. Only one in five graduates are willing to start their own business; in the fields of physics, mathematics and statistics, there are no graduates prepared to start their own business at all. The majority of self-employed workers indicate that they are satisfied with their work and earnings. Young people expressing the desire to go to work abroad are most often graduates of basic vocational schools, technical colleges and profiled high schools. They are usually men who, at the same time, rate their English language skills among the lowest [45]. An equally significant phenomenon in the labor market is the loss of unique professional qualifications and vast professional experience, as a result of premature deactivation of people aged over 50 years and more. This phenomenon is associated with the process of disappearance of the student and master relationship known as mentoring [46] (pp. 177-194) which is important for young people. The above-mentioned challenges, it seems, clearly indicate the importance of scientifically shaped market assessments and analyses. As past and present phenomena and processes indicate, special importance in labor market policy should be attributed to the available form of supporting the smooth transition of young people from education to the labor market and the possibility of long professional activity of people aged over 50 .

Based on the before mentioned processes and trends for Silesian Voivodeship, increased adaptability and the adaptation of human resources to the labor market will be of utmost importance. The need to identify trends in education profiles in relation to the needs of the regional labor market, as well as to analyze the needs of employers and development trends by sector, are extremely important. Undertaking the indicated activity may significantly condition the development of the education and vocational education system at every level. In light of this challenge, it is important to clearly state 
that the problem of demand for qualified staff in the labor market is well documented, especially in economics, as well as sociology and social policy. On the basis of the knowledge from these fields and disciplines of science, an answer is being sought to the question of future staffing needs in an economy determined by the process of globalization and, as already mentioned, three key changes: climate, technology and demographic.

It is worth noting here that education is an essential part of the global response to climate change. It helps young people to understand and address the impact of global warming, encourages them to change their attitudes and behavior and helps them to adapt to climate change trends. With the 'Climate Change Education for Sustainable Development' program, UNESCO aims to make climate change education a more central and visible part of the international response to climate change. The program aims to help people understand the impact of global warming today and increase 'climate literacy' among young people. It does so by strengthening member states' capacities to provide quality climate change education; encouraging innovative approaches to teaching to integrate climate change education into schools and by raising awareness of climate change and improving non-formal education programs through the media, networks and partnerships [47].

Taking into account the numerous studies addressing the problems of the contemporary world from an educational perspective, it is proposed to prepare the global society for the challenges resulting from the identified problems based on the scenarios of the future labor market [48]. In the context of the above regularity, it is worth presenting five scenarios on what the work of the future might look like. On the basis of the scenarios indicated, it is possible to initiate a discussion on the shape of contemporary education programs in a perspective corresponding to future human resources needs and changing labor markets.

Five scenarios for the future of work were developed on the basis of these changes [49]. According to the first of the scenarios titled "Working Forever", as a result of social and technological change, associated primarily with the development of medicine, technology, education and production of healthy food, life expectancy will significantly increase. This will lead to the scenario in which, in the near future, people will be professionally active much longer than it they are today. Their professional activity can be extended up to the age of 80 or 90 . In this scenario, it should be expected that a change of profession and retraining will accompany a person throughout their entire professional career.

In the second scenario entitled "The Useless Class", there is a significant increase in technologies related to artificial intelligence (a field of knowledge including fuzzy logic, evolutionary calculations, neural networks, artificial life, robotics and artificial intelligence (AI)), technologies that enable computer systems to interact with people using voice and tones (interactive voice response (IVR) systems), processes of automating the analysis, and understanding, translating and generating natural language by computer systems (natural language processing (NLP) networks). As a result of the changes caused by the above factors, major reevaluations in the labor market should be expected in the near future. In this scenario, we may find a lonely, passive, immersed and lost individual in the virtual world and, in an extreme variant, the individual could be subordinate to machines. In the short term, this scenario assumes the integration of AI solutions with human work. In the long-term perspective, it should be expected that solutions from the AI area will enter fields previously dominated by human work.

The third scenario was dominated by the process of focusing work only on yourself, hence the title of this scenario being "People Per Hour". This form of future work on the market is dominated by young people, modern teenagers and people aged 20-30 (generation $\mathrm{Z}$ and millennials) expecting, above all, flexible forms of work. These people contest traditional forms and work models based on an eight-hour and stationary day and place of work, striving for maximum personal development and professional promotion.

In the fourth scenario entitled "There Are No Jobs on a Dead Planet", climate change is the decisive factor in one's future work vision. As a result of its development, an increase in migration processes from inland areas and, geographically, the lowest inland areas is unheard of in human history. This will 
mainly affect city dwellers, most of which are located 100 kilometers from the coastlines of rivers, seas and oceans. People will also leave areas threatened by droughts, storms, floods or typhoons and other types of extreme climate phenomena unknown today. As a result, processes and phenomena, such as the disappearance of labor markets characterized by clusters of entrepreneurial, creative people with unique and highly developed qualifications, can be expected. These are also markets in which information- and knowledge-focused, unique ideas will emerge, along with outstanding business solutions. Therefore, this scenario foresees that climate change will trigger economic crises and related unemployment, a decline in investment and a decrease in consumption.

The fifth and final scenario is entitled "Through the Glass Door". In this scenario, transparency and trust are decisive. As the scenario writers note, the development of social media means that transparency and information flow are perceived differently than in previous decades. This is confirmed, for example, by the dynamic increase in the number of social organizations that aim to civically control the activities of public authorities or the ethics of big business activities and people exposing improper activities or improper practices applied by companies employing them. Thus, transparency and clarity affect the state of the economy. As many studies show, people show greater confidence in transparent companies and are much more likely to buy their products or services. In this scenario, it is anticipated that the global economy will face the challenge of hyper-transparency. This means, in practice, that companies will be aware that everything that is associated with their business can be made public.

In the context of the scenarios described above, it is interesting to anticipate the process of the growth and development of the digital society [50]. Currently, individuals, being an element of a network community, are becoming a part of a network connecting people with devices in a complicated communication system. Access to the system is enabled by interfaces, technological solutions that are the link between the human world and machines, and between machines themselves. The interfaces and logic of the system's operation create affordances that outline the area of the objective independence of the individual in technical civilization. Progress in the development of interfaces fully correlates with the development of anthropotechnics that lead to, in an optimal way, the adaptation of positions, processes and the work environment to psychophysical potential of individuals, in order to protect their life and health and create opportunities for the most complete personal development. In other words, these affordances are associated with the human body. The resulting applications can, in this case, perform therapeutic functions, e.g. implants inserted into the brainstem to restore hearing. On this basis, hypotheses are formulated in which an individual is increasingly integrated with the technical systems surrounding them and takes the form of a cyborg. As indicated by numerous expert opinions, another process is currently underway, as a result of which it can be expected that in the near future, two currently binding languages in the world, which are one's native language and one selected foreign language, will be joined by another coding language [51]. The phenomenon of affordance described above is associated with the dynamically progressing process with increasing significance on, among others, the economic processes of the phenomenon of digitization. The term "digital society" is becoming more and more common [52]. In connection with this term formed, in this way, this class determines the process in which digital knowledge becomes the foundation of the power of the global economy. In such a world, digital creativity and curiosity prevail and these are the characteristics that mainly characterize young people [52].

In the growth and development of the digital society, in a globalized and determined demographic world, it is worth referring to problems related to environmental protection. Indeed, in addition to the advantages of globalization, this process also has significant disadvantages, one of which is the negative impact of globalization on the environment, manifested, inter alia, in the transfer of so-called "dirty technologies", i.e., the transfer of production to regions of the world with lower environmental standards in order to minimize production costs [53]. Thus, this sphere is particularly associated with the need to raise the awareness of an aging society in order to stop further environmental degradation. Environmental education is assigned a special role in this process [54] (pp. 43-57). The importance of environmental education began to increase already since the 1970s. The world's first intergovernmental 
conference on environmental education was organized by the United Nations Education, Scientific, and Cultural Organization (UNESCO) in cooperation with the U.N. Environment Programme (UNEP) in Tbilisi, Georgia, in October 1977. During that conference, the formal definition of environmental education was agreed and the basic guidelines for environmental education for all age groups at local, regional, national and international levels were developed [55].

Environmental education, defined as a process aimed at developing the human population, builds the scientific basis for presenting the natural environment as of overriding value for the human and his health and life [54]. This awareness development is conscious and includes knowledge, attitudes, skills and motivations, as well as the duty to work individually and in groups to solve and prevent existing problems concerning the environment [56]. This way, properly understood environmental education should be equated with comprehensive lifelong education, enabling response to transformations in a rapidly changing world, thanks to which a person should understand the main problems of the modern world and have the skills necessary to play a productive role in improving life and protecting the environment, with due regard for ethical values [57].

In principle and for many years, use of the terms "ecological education" and "environmental education" have been treated interchangeably [58], although some scientists have stressed that in many countries, environmental education often focuses only on information on environmental problems, such as water quality in local rivers, protected areas, endangered species or global climate change, which does not correspond to the principle that education should be a tool for the development of a citizen capable of making wise and responsive decisions on the impact of human activity on the environment [59]. Additionally, environmental education is often both inadequate and ineffective because too little attention is paid to the external influences of its cultural, scientific and political context. Therefore, it is necessary to address the interrelation of environmental policy, public awareness and environmental education [60]. Based on that, some researchers decided to use the term ecological education as an "extended form of environmental education", which emphasizes the perception of man as a part of the natural world and the obligations which result from this relationship, instead of treating the natural environment as a separate element which is influenced by man from outside [59].

In Poland, the National Environmental Education Strategy Through Education for Sustainable Development developed in the 1990s has identified and prioritized the main objectives of environmental education, while indicating the possibilities of their implementation [61]. One of the basic provisions of the Strategy is the assumption that environmental education should cover the whole society, including all age and professional groups, as well as decision makers at the central and local level. However, despite their existence, both the strategy and its implementing document, the National Ecological Education Programme, have been for many years a collection of wishes addressed to various institutions, rather than a plan for the systematic development of society in the field of ecology [54]. As a result of regional foresight research, conducted in the Silesian Voivodeship, it was noted that in order to achieve a real improvement of social capital, the implementation of tasks related to education and upbringing (including environmental education) should be carried out systematically, on a supra-local scale and, in the case of metropolitan areas, on a metropolitan scale service [62].

The development of environmental education programs for local communities, aiming at goals of local and regional development, should be organized with the help of specialists in such a way as not to exclude older people from this process, because only allowing adults to improve their environmental knowledge and awareness within both formal and informal education systems allows a real change of awareness. In line with these aims, in current years many bottom-up activities, both in the country and in the Silesian Voivodeship, have been undertaken, differing from digitalization of cultural and natural resources of the Silesian Voivodeship and use of VR technologies in ecological education, as well as developing various forms of tourism, including ecotourism, as an impulse to implement solutions shaping ecological awareness and sensitivity of adults and children. The growing possibilities of using VR technology in environmental education-both in innovative curricula of geography and environmental science, biology, physics and chemistry, as well as in tourism-fits into the general 
trends of digitization and globalization and allows not only increase of knowledge, but also better "accessibility" of natural valuable areas for the elderly or people with reduced mobility. The possibility of presenting the appearance and characteristics of natural elements in different time perspectives, using VR technology has an "emotional" impact (supported by technical data), which can contribute to increased understanding and awareness about environmental issues and sustainable management of resources [63].

Moreover, the strengthening of the promotional function, through the use of modern presentation technologies to show the changes taking place in the region and increasing the potential of virtual tourism, minimizes the excessive burden on the natural environment of some areas of the voivodeship. Developed solutions are intensively seeking synergies between the economic, environmental and social aspects of functioning, having in mind that the best and quickest way to raise adults' environmental awareness is to involve as many residents as possible in the decision-making processes [61].

On the above-mentioned plane of climate, demographic and technological change is developing a process of using digital technologies to create innovation. They are shaped and expressed through the process of convergence between nano-, biological and information technologies, as well as cognitive sciences (hereinafter NBIC technologies). NBIC technologies are developing extremely dynamically, creating progress in the sphere of health protection, energy, environmental protection and production, leading to the transformation of other non-technical areas, outside of their impact. As a result, the convergence process determines integration, openness and comparability, leading to visionary solutions. An equally important consequence of convergence is the creation of internal and external cooperation in creating innovations and overcoming mentality barriers towards innovations in order to strengthen their acceptance. On one side, in the area of the labor market, the process of using digital technologies to create innovation is increasingly driven by both the needs of the demographic and digital society and the ongoing climate and technological change.

On the other side, digitization determines the disappearance and emergence of new professions. Researchers from the University of Warsaw DELab center in a joint report with Gumtree.pl warn that, in the next 25 years, automation and robotization in Poland may threaten approximately $40 \%$ of professions [64]. A recent report by the Organization for Economic Cooperation and Development, which analyzes 32 countries participating in the survey on adult competences (PIAAC), estimated that 48 percent of work is susceptible to automation. In Poland, 52\%, among others, are at risk specialties underpinning the development of the modern business services sector [65]. In this light, one of the current discussions is the shape of the labor market and the enterprise of the future. For example, Handy claims that in the near future, over $70 \%$ of jobs in enterprises will be related to knowledge, not physical work [66] (p. 19). Another approach believes that in 20 years, a typical large enterprise will more resemble knowledge-based hospitals or symphony orchestras than the production facilities known today. The future, therefore, belongs to enterprises whose strategic resource corresponds to the formula: information + knowledge + creativity. Such enterprises-or more broadly social systems-are proposed to be called intelligent systems [67]. However, enterprise intelligence is very difficult to measure and even more difficult to manage. Therefore, it is worth remembering that in a globalized and internationalized economy, it is necessary to optimally extract every bit of intelligence from each student and employee [68].

The future of qualified personnel on labor markets is equally widely analyzed and described on the basis of strategic documents defining the future of given areas. In this light, records derived from the Regional Strategy for the Innovation Development of the Silesian Voivodeship for the years 2013-2020 (RIS) [69] have proven to be extremely valuable. This strategy is an important document outlining development directions, including for the Upper Silesian-Zagłębie Metropolis. Taking into account the successful development of qualified staff, it is certainly necessary to orient their education in accordance with the areas with the greatest potential for technological development in the voivodeship [70], which includes, among others: energy, medicine, information and telecommunications technologies, emerging industries and green economy. 
In this light, nationwide works related to labor market challenges in the context of the demand for qualified staff are also important in connection with the following areas: automation and robotics, construction and civil engineering, logistics and transport engineering and environmental engineering. In turn, from remark horizontal (prospective) fields, it is indicated for: IT and internet services, biotechnology, medicine and health care, finance, education and security [44] (pp. 123-128).

In turn, by analyzing current economic trends and information from Silicon Valley, an attempt can be made to predict the professions of the future [71]. It seems that they will be related to areas such as digitization, cyber security, artificial intelligence (a field of knowledge including fuzzy logic, evolutionary calculations, neural networks, artificial life and AI robotics) and will also be based on the ideas of personalization and humanization. [72]. On the basis of the phenomena, processes and trends indicated above, attempts are being made to anticipate future staffing needs, and to shape qualification and competence requirements based on them. An example reflecting the attempts made are already recognized new and hitherto unknown professions, such as the robot trainer, whose presence on the labor market will guarantee the development and competitiveness of economies. The need to train qualified staff in this profession is caused by the development of artificial intelligence. This phenomenon implies a state in which autonomous robots will soon be partners of people in the real world. Another example of a previously unknown profession is an ethical hacker focused on cyber-crime, whose task is to hack into the systems of companies at their own request, thus looking for and locating possible vulnerabilities in the system in order to protect it from a real attack. The example of people dealing with reality architecture-called world architects-is another interesting new profession; people with this profession will deal (with the support of traditional architects and programmers) with arranging smart cities. To conclude, attempts to predict which new profession will be created in the next year or in a few years are numerous and certainly many new professions will come as a big surprise. Many futurologists mention possible future professions including: tissue engineer, aquaponic fish breeder [73], gene programmer, virtual reality actor, fauna and flora revitalizer, genetically modified organism controller and Turing tester [74] (pp. 437-441).

Certainly, changes in the labor market will be affected by increasing specialization-effectively, specialists will appear who will deal with a small slice of reality, using very detailed knowledge. As the researchers note, the world is becoming more and more complicated and it seems that a soon-to-be-awaited profession will be a translator who will try to explain everything. On the level of the above indications and forecasts, there is also a precise list of professional competences that can be considered characteristic and necessary in the phase of the Industrial Revolution 4.0. These include interdisciplinarity, speed of action, innovative and adaptive thinking, computational thinking and intercultural competence [75] (pp. 11-27). In this light, modernity and the social and economic processes that shape it also enforce the need to have the competences referred to as the 'future'. These include: teamwork skills, ability to work in information noise, virtual cooperation skills, "real" communication skills and project work skills. Against this background, it is assumed that the main skills for success in a globalized and internationalized economy will be the following skills: learning speed as well as mobility and adaptability [76].

It is worth emphasizing that the modern paradigm of the knowledge-based economy should take into account the fact that human needs are met in the process of production and services. In this context, it is thanks to education that knowledge "spreads" in all sectors of the economy. Economists and social politicians provide convincing tangible evidence of the benefits of education. Economic benefits illustrate the differences in earnings between people with different levels of education. In more than two thirds of OECD countries, people with higher education have $50 \%$ higher earnings compared to people with upper secondary and post-secondary education. From a macroeconomic point of view, investing in education is profitable. In OECD countries, a person with higher education during the period of professional activity brings the state budget income from taxes and insurance contributions of an average of approximately USD 100,000 more than compared to a person with secondary education. 
After deducting public funds allocated to financing student education in higher education, the net benefit is over USD 91,000 [77].

\section{Conclusions}

In light of the above, there can be no doubt that education responding to contemporary challenges is a guarantee of promoting knowledge and profiling mobile and adaptive qualified staff who are characterized by having a specific level of knowledge, qualitatively unique skill and highly developed qualifications [78] (pp. 145-155). Such staff constitute a basic resource of labor supply and each organization. Well qualified staff in the surrounding economic reality can minimize structural stratification in the labor market, eliminate the mismatch of professional qualifications to the needs of employment, limit the increase in unemployment and ultimately decide on economic growth and the success of an enterprise's mission. As it is noted in research in the area of the labor market, in particular in the field of organization and management, in the recent past, competitive advantage on the market was demonstrated by enterprises with relatively complex capital resources, which were most often technologies, raw materials and labor resources, etc.

Currently —as indicated by research in the field of management-the enterprises which dominate the market have staff who are appropriately educated, modern, intelligent, sensitive to changes and efficiently and effectively use their potential to achieve the assumed economic goals and accomplish the mission of the company [79] (pp. 213-240). The dominant theme in these activities is-as has already been noted before-a modern and innovative education system which responds to contemporary and future challenges at every level of training; a system which, in line with short and medium-term economic goals and megatrends in phase II of the demographic transition and globalization, determines the successful development of the two most important human and social capital in the modern world and the human attitudes resulting from them: the universality of ideas and the ability to create and accumulate them around them the most creative individuals, norms of behavior and, above all, a climate for the fulfillment and success of the individual in the contemporary and changing world with dynamics, which are to date unknown [80] (pp. 5-26). In this context, special importance should be attached to the literature of E. Rostańska, who notes that education should be seen as a value in all social and individual declarations. It should refer to the inspiration of changes, to the stimulation of development and also to human stability. It is also seen as the perpetrator of activity and as an object of human activity. Therefore, learning is the value of modern times and, at the same time, a requirement that is necessary for dignified functioning in society. Hence, there is the undeniable view of the strength and value of education in every social situation presented [3] (p. 162).

Author Contributions: Conceptualization, R.M. and L.D.; methodology, R.M., P.H. and M.M.; validation, R.M., L.D.; formal analysis, P.H. and M.M.; resources, L.D.; data curation, R.M. and P.H.; writing-original draft preparation R.M., P.H., L.D., M.M.; writing-review \& editing, R.M., P.H.; L.D., M.M.; visualization, R.M.; supervision, R.M. and L.D.; All authors have read and agree to the published version of the manuscript.

Funding: The publication is financed within the framework of the program titled DIALOG ("Dialogue") introduced by the Minister of Science and Higher Education between 2016-2019.

Conflicts of Interest: The authors declare no conflict of interest.

\section{References}

1. Schlotter, M.; Schwerdt, G.; Wößmann, L. The Future of European Education and Training Systems: Key Challenges and Their Implication; EENEE: Munich, Germany, 2008.

2. Matusiak, M. Professions of the future. In Innovation and Entrepreneurship for the Future; Gromada, G., Matusiak, M., Nowak, M., Eds.; SOOIPP Annual-2006; SOOIPP: Łódź, Poland; Warsaw, Poland, 2006.

3. Rostańska, E. Picture of Education and Its Recipients in the Context of Experiencing Changes, WSB Academy in Dąbrowa Górnicza, ed.; Digital Press Lidia Jaworska: Będzin, Poland, 2018.

4. Van de Kaa, D.J. Europe's Second Demographic Transition. In Population Bulletin, 42, 1; Population Reference Bureau Inc.: Washington, DC, USA, 1987. 
5. Sztanderska, U. Demographic Future and Education; Labour Market Research Center. University of Warsaw: Warsaw, Poland, 2020. Available online: https://www.rpo.gov.pl/pliki/12460171710.pdf (accessed on 8 April 2020).

6. Landry, A. La Révolution Démographique; International Affairs: Paris, France, 1934.

7. Łobodzińska, A. An Aging Society as A Challenge for Sustainable Development. Geographic Works; Institute of Geography and Spatial Management of the Jagiellonian University Kraków: Krakow, Poland, 2016.

8. Marszowski, R. Demographic regress in Silesian Voivodeship. Sources and Consequences. Int. Soc. Humanit. Stud. Hum. 2017, 25, 127-142.

9. Kabisch, N.; Haase, D.; Haase, A. Urban population development in Europe 1991-2008: The examples of Poland and UK. Int. J. Urban Reg. Res. 2012, 36, 1326-1348. [CrossRef]

10. Lesthaeghe, R. The Unfolding Story of the Second Demographic Transition. Popul. Dev. Rev. 2010, 36, 211-251. [CrossRef] [PubMed]

11. The Silesian Voivodeship Economic Information; Marshal Office of the Silesian Voivodeship: Wrocław, Poland, 2017.

12. Krzysztofik, R. Cities. In Silesian Voivodeship, Geographical and Economic Outline; Tkocz, M., Ed.; Faculty of Earth Sciences of the University of Silesia: Sosnowiec, Poland, 2006.

13. Runge, A. Processes and population structures in the Silesian Voivodeship. In Demographic and Social Processes and Structures in the Silesian Voivodeship in 1988-2008; Statistical Office in Katowice: Katowice, Poland, 2010.

14. Runge, J. Regional and local consequences of contemporary demographic changes in Poland, elements of research methodology. An example of the Silesian Voivodeship. In Studia Ekonomiczne; No. 223; Zeszyty Naukowe Uniwersytetu Ekonomicznego w Katowicach: Katowice, Poland, 2015.

15. Eberhard, P. Phases of the demographic change in Poland. Rocz. Nauk Społecznych 2014, 6, 135-160.

16. Kiełkowska, M. (Ed.) Labour Market and Demographic Changes; Demographic Notebooks No. 1; Citizens' Institutes: Warsaw, Poland, 2013.

17. Sojka, E. Assessment of demographic changes in Poland in the years 1950-2013 using multidimensional comparative analysis methods. In Studia Ekonomiczne; No. 324; Zeszyty Naukowe Uniwersytetu Ekonomicznego w Katowicach: Katowice, Poland, 2017.

18. Raczaszek, A. (Ed.) Demographic determinants of social development. In Studia Ekonomiczne; Zeszyty Naukowe Uniwersytetu Ekonomicznego w Katowicach: Katowice, Poland, 2012.

19. Hrynkiewicz, J.; Potrykowska, S. (Eds.) Demographic Situation of the Silesian Voivodeship as a Challenge for Social and Economic Policy; The Government Population Council: Warsaw, Poland, 2017.

20. Local Data Bank Website. Available online: https://bdl.stat.gov.pl/BDL/start (accessed on 6 March 2020).

21. Population Projection 2014-2050; Statistical Analyses and Studies; Central Statistical Office: Warsaw, Poland, 2014.

22. Demographic forecast for 2014-2050 for the Silesian Voivodeship; Statistical Office in Katowice: Katowice, Poland, 2015.

23. Rauziński, R.; Zagórowska, A. Socio-demographic changes in Silesia in the years 2002-2011 and their prognostic implications. In Economic Studies No. 197. Education in the Light of Changes in the Contemporary Labour Market: Selected Problems; University of Economics in Katowice: Katowice, Poland, 2014.

24. Gołaszewska-Kaczan, U. Actions raising the level of human capital in the new financing perspective 2014-2020, Optimum. Studia Ekon. 2014, 62, 91-104.

25. Becla, A.; Czaja, S. The role of human and social capital in determining the path of economic development in problem regions. Optim. Studia Ekon. 2014, 62, 16-28. [CrossRef]

26. Przymeński, A. The development of social capital and its factors. In Theoretical Aspects of Social Capital; Januszek, H., Ed.; Zeszyty Naukowe AE: Poznań, Poland, 2004; No. 42.

27. Pogonowska, B. Social Capital-An attempt to reconstruct the conceptual category. In Theoretical Aspects of Social Capital; Januszek, H., Ed.; Zeszyty Naukowe AE in Poznań; Wydawnictwo AE: Poznań, Poland, 2004; No. 42.

28. Dicken, P. Global Shift. The Internationalization of Economic Activity; Guilford Press: New York, NY, USA; London, UK, 1992.

29. Liberska, B. Globalization. Mechanisms and Challenges; PWE: Warsaw, Poland, 2002.

30. Zaorska, A. Towards Globalization? Changes in Transnational Corporations and in the Global Economy; PWN Scientific Publisher: Warsaw, Poland, 2000; ISBN 83-01126-73-6.

31. Koch, R. Dictionary of Management and Finance; Tools, terms, techniques from A to Z; Professional Business School: Krakow, Poland, 1997. 
32. Levy, D.L. International Sourcing and Supply Chain Stability. J. Int. Bus. Stud. 1995, 26, 343-360. [CrossRef]

33. Stiglitz, J.E. Globalization; PWN: Warsaw, Poland, 2007.

34. Wolf, M. Will the Nation-State Survive Globalization? Foreign Aff. 2001, 80, 178. [CrossRef]

35. Parlińska, M. Economics of information on the Background of the Global Society Development. Scientific Journal, Warsaw University of Life Sciences Problems of World Agriculture. ICI World J. 2015, 15. [CrossRef]

36. Klimska, A. Tasks of education in the face of knowledge-based economy. In Education in a Globalized World; Tanaś, V., Welskop, W., Eds.; Scientific Publisher of the College of Business and Health Sciences: Łódź, Poland, 2015.

37. Łęcka, I. Social consequences of globalization. Globalization and public safety and health. University of Warsaw, Warsaw 2007. In The Role of Education in Globalization Processes; Borowiec, M., Ed.; Pedagogical University of Cracow: Cracow, Poland, 2011.

38. Lewandowski, P.; Rutkowski, L. (Eds.) Population Aging, Labour Market and Public Finances in Poland; Representation of the European Commission in Poland: Warsaw, Poland, 2017.

39. Official Journal of the European Union (2018/C 237/02). Opinion of the European Economic and Social Committee 'The Future of Work-Acquiring the Right Knowledge and Skills to Meet the Needs of the Future Labour Market'; Official Journal of the European Union: Brussels, Belgium, 2018.

40. Marszowski, R. Young mining personnel-Barriers and determinants of professional development in the phase and promotion during the Industrial Revolution 4.0. Min. Rev. 2019, 3, 15-23.

41. Borowiec, M. The Role of Education in the Globalization Process; Pedagogical University of National Education Commission in Krakow: Krakow, Poland, 2011.

42. Jastrzębska, D.; Dzienisiewicz, M.W. (Eds.) Quality of Education as a Result of Strategic Management; Center for Education Development: Warsaw, Poland, 2011.

43. Federowski, J. Directions of Development of the Silver Economy-Forecasts for Poland in the Context of Global Trends; Employers of the Republic of Poland: Warsaw, Poland, 2015.

44. Matusiak, K.B.; Kuciński, J.; Gryzik, A. Foresight of the Staff of Modern Economy; Polish Agency for Enterprise Development: Warsaw, Poland, 2009.

45. Jelonek, M.; Kasparek, K.; Magierowski, M. Young People on the Labour Market-Employees, Entrepreneurs, the Unemployed; Polish Agency for Enterprise Development: Warsaw, Poland, 2015.

46. Ślęzak-Gładzik, I. Mentoring as a method of Developing the Potential of Employees. Coaching Review 12016 , 8, 177-194. [CrossRef]

47. Global Action Program for Education for Sustainable Development (2015-2019); UNESCO: Paris, France, 2020.

48. Lesson with the Climate. Educational Package. Lesson Plans and Supporting Materials; Ministry of Agriculture of the Republic of Poland: Warsaw, Poland, 2010.

49. Work. Future Scenarios (Report); In future Hatalska Foresight Institute: Hawthorn, Australia, 2016.

50. Understanding the European Union's policy-Digital Agenda for Europe; European Commission Directorate-General for Social Communication Citizens' Information Department: Brussels, Belgium, 2014.

51. Hapaniuk, M. E-Wave on the Labour Market; Civic Institute: Warsaw, Poland, 2013.

52. Action Plan of the Minister of Digitization-Attachment to the Integrated State Computerization Program; National Integrated Informatisation Programme (PZIP): Warsaw, Poland, 2016.

53. Dybek, K. Environmental destruction as a negative effect of globalization processes. In Inter-Faculty Studies in Environmental Protection; University of Warsaw: Warsaw, Poland, 2001; Available online: http: //zm.org.pl/?a=globsrod (accessed on 26 February 2020).

54. Tuszyńska, L. Ecological education in the perspective of sustainable development. Studies in Global Ethics and Global Education 2017, 3, 43-57. [CrossRef]

55. Tbilisi Declaration. 1997. Available online: http://www.gdrc.org/uem/ee/tbilisi.html (accessed on 27 January 2020).

56. Kozaczyński, W. Ecological Education of Secondary School Children in Selected Regions of Southeastern Poland; Wydawn. Naukowe Akademii Pedagogicznej: Kraków, Poland, 2003.

57. Gillet, M. The Tbilisi Declaration. McGill J. Educ. 1997, 12, 243-245.

58. Terlecka, M.K. About ecological education in Poland. In Ecological Education-Selected Problems; Armagraf: Krosno, Poland, 2014.

59. Smith, G.A.; Williams, D.R. Ecological Education: Extending the Definition of Environmental Education. Aust. J. Environ. Educ. 1999, 15, 139-146. [CrossRef] 
60. Schleicher, K. Beyond environmental education: The need for ecological awareness. Int. Rev. Educ. 1989, 35, 257-281. [CrossRef]

61. Through Education for Sustainable Development-National Environmental Education Strategy; Polish Ministry of Environment: Warsaw, Poland, 2001.

62. Trzaski, L.; Tausz, K.; Kopernik, M.; Korczak, K.; Marszowski, R. Conditions and prospects for the metropolisation of public services of the Upper Silesian Metropolitan Area in the light of the findings of the Horizontal Panel. In Vision of the Future of Metropolitan Public Services in the Upper Silesian Metropolitan Area; Bondaruk, J., Ed.; Central Mining Institute: Katowice, Poland, 2011.

63. Kruczek, M. (Ed.) On-Going Evaluation of the Implementation of the Technology Development Program of the Silesian Voivodeship for 2010-2020; Collective Work, Central Mining Institute, Marshal's Office of the Silesian Voivodeship: Katowice, Poland, 2018.

64. Active. In The Future of the Labour Market 2017; Gumtree Report; OECD: Paris, France, 2017.

65. Poles' Skills—Results of the International Adult Competence Survey (PIAAC)—Report 2013; IBE: Warszawa, Poland, 2013.

66. Handy, C. The Age of Overcome Reason; Harvard Business Review Press: Warsaw, Poland, 1998.

67. Drucker, P.F. Post-Capitalist Society; PWN: Warsaw, Poland, 1999.

68. Matsushita, K. Management with Passion; Pawlak, W.R., Ed.; Conversations with Konosuke Matsushita, the Founder and Creator of the Power of the Matsushita Corp. group (Panasonic, Technics, National), Forum; Wiley: Hoboken, NJ, USA, 2004.

69. Regional Innovation Strategy of the Silesian Voivodeship for the Years 2013-2020; European Commission: Katowice, Poland, 2012.

70. List of Smart Specializations of the Silesian Voivodeship, Uchwała nr V/50/1/2018 Sejmiku Województwa Ślaskiego z Dnia 19 Marca 2018 r. w Sprawie Aktualizacji Listy Inteligentnych Specjalizacji Województwa Ślaskiego/Resolution no V/50/1/2018 of 19 March 2018 on Updating the List of Smart Specialisations of Silesian Voivodship, Katowice 2018. Available online: https://www.scp-slask.pl/czytaj/zaktualizowana_lista_ inteligentnych_specjalizacji_wojewodztwa_slaskiego (accessed on 13 April 2018).

71. Three Promising Future Professions That You May Have Had No Idea. Available online: https://businessinsider.com.pl/technologie/trzy-rokujace-zawody-przyszlosci-o-ktorych-istnieniubyc-moze-nie-miales-pojecia/e3xfy6w (accessed on 27 February 2020).

72. Rich, E.; Knight, K. Artificial Intelligence; McGraw-Hill Science: New York, NY, USA, 1990.

73. Sadowski, J. Akwaponika-A Real Solution or a New Religion? Available online: Http:// ekologicznarybawygkuje.pl/wp-content/uploads (accessed on 8 April 2020).

74. Łupkowski, P. Some historical remarks on Block's “Aunt Bubbles" argument. Minds Mach. 2006, 16, 437-441. [CrossRef]

75. Sopińska, A. Creativity and innovation of the organization. Open innovation as a manifestation of co-creativity. In Studies and Work of the Collegium of Management and Finance 161; SGH Warsaw School of Economics: Warsaw, Poland, 2018.

76. Głąb, K.; Kniaź, A. Competences of the Future in Times of Digital Disruption. Study of Challenges for Poland until 2030; Cities on Internet Association, Evidence Institute Scientific Foundation: Warsaw, Poland, 2019.

77. Education at a Glance; OECD: Paris, France, 2011.

78. Slubok, A. Challenges of the contemporary school in the age of globalization. In Education in a Globalized World; Tanaś, V., Welskop, W., Eds.; Scientific Publisher of the College of Business and Health Sciences: Łódź, Poland, 2016.

79. Marszowski, R. Qualified staff on the labour market. The most valuable resource of modern economies. Soc. Educ. Int. Stud. Humanit. 2018, 29, 213-240.

80. Marszowski, R. Education and active social policy towards development challenges in the Pszczyna poviat. Soc. Educ. Int. Stud. Humanit. 2018, 29, 5-26.

(C) 2020 by the authors. Licensee MDPI, Basel, Switzerland. This article is an open access article distributed under the terms and conditions of the Creative Commons Attribution (CC BY) license (http://creativecommons.org/licenses/by/4.0/). 